Online: http://journal.uny.ac.id/index.php/jppfa

\title{
PENDAYAGUNAAN MODAL SOSIAL DALAM PENDIDIKAN KARAKTER
}

\author{
Kurotul Aeni, Zamroni, Darmiyati Zuchdi \\ Universitas Negeri Semarang, Universitas Negeri Yogyakarta, Universitas Negeri Yogyakarta \\ aeni.kurotul@gmail.com,
}

\begin{abstract}
Abstrak
Penelitian kualitatif dengan pendekatan naturalistik studi kasus ini bertujuan menganalisis bentuk, perbedaan, dan ciri khas pendayagunaan modal sosial dalam pendidikan karakter di SD Sapen dan SD Budi Mulia Yogyakarta. Pengumpulan data menggunakan observasi, wawancara, dan dokumentasi. Keabsahan data dilakukan dengan konfirmasi hasil observasi, wawancara, dokumen wawancara. Uji kredibilitas data dilakukan dengan memperpanjang pengamatan, meningkatkan ketekunan, triangulasi data, analisis kasus negatif, member check, dan referensi. Analisis data menggunakan model interaktif Miles \& Huberman. Hasil penelitian menunjukkan pendayagunaan modal sosial dalam pendidikan karakter yang dilaksanakan dalam kegiatan pembelajaran, budaya sekolah, dan program karakter melalui inkulkasi nilai karakter dan keteladanan secara integral memperkuat karakter. Pendayagunaan modal sosial pada kegiatan ekstrakurikuler berpengaruh sangat kuat terhadap pembentukan karakter dibandingkan kegiatan intrakurikuler.
\end{abstract}

Kata kunci: pendidikan karakter, modal sosial, program afektif, kedisiplinan, penugasan, living value, happy learning

\section{EMPOWERING THE SOCIAL CAPITAL IN THE CHARACTER EDUCATION}

Kurotul Aeni, Zamroni, Darmiyati Zuchdi

Semarang State University, Yogyakarta State University, Yogyakarta State University aeni.kurotul@gmail.com, zamroni1947@gmail.com,darmiyati@uny.ac.id

\begin{abstract}
The qualitative study by means of naturalistic case study approach was to analyze the form, the difference and the peculiarity of empowering the social capital in the character education conducted in the Muhammadiyah Sapen Elementary School and the Budi Mulia Dua Elementary School Yogyakarta. The data gathering was conducted by implementing observation, interview and documentation. The data validity was measured by confirming the results of observation, interview and interview document. The data credibility test was conducted by lengthening the observation, increasing the persistence, triangulating the data, analyzing the negative case, performing member checking and finding references. For the data analysis, the researcher made use of Miles\& Huberman interactive model. The results of the study showed that empowering the social capital in the character education that had been implemented in the form of learning activities, school culture and character programs by means of inculcation toward the character values and the role modelling integrally strengthened the students' characters. Empowering the social capital in the extracurricular activities influenced heavily the character formation than in the intracurricular activities.
\end{abstract}

Keywords: character education, social capital, affectiv programs, discipline, assignment, living value, happy learning 



\section{PENDAHULUAN}

Pelaksanaan pendidikan di sekolah tidak terlepas dari kegiatan pembelajaran intrakurikuler maupun ekstrakurikuler. Kegiatan pembelajaran terjadi sebagai hasil interaksi antara guru - peserta didik, peserta didik-guru, dan peserta didik dengan peserta didik. Kemitraan antara peserta didik dengan guru, dan sebaliknya sangatlah menentukan keberhasilan dalam pembelajaran. Peserta didik sebagai individu merupakan bagian dari peserta didik yang lain. Kemandirian manusia tidak diartikan sebagai hidup sendiri secara tunggal, tetapi hidup yang harmonis dan adaptif dalam tatanan kehidupan bersama.

Pembelajaran di sekolah dewasa ini masih banyak dijumpai berada pada tataran kognitif saja, belum mengembangkan aspek afektif dan aspek keterampilan. Masih banyak ditemukan pembelajaran yang menitikberatkan pada hafalan-hafalan (penguasaan konsep). Masih ada anggapan yang keliru bahwa pengembangan aspek kognitif sekaligus atau otomatis mengembangkan aspek lainnya yaitu afektif dan psikomotor. Sebagaimana dikatakan oleh (Suyanto, 2000, pp. 153-154) bahwa pengabaian kawasan afektif merugikan perkembangan peserta didik secara individual maupun masyarakat secara keseluruhan. Peserta didik tahu banyak tentang sesuatu, namun mereka kurang memiliki sikap, minat, sistem nilai, maupun apresiasi secara positip terhadap apa yang mereka ketahui.

Hal ini menunjukkan bahwa perlu diciptakan lingkungan belajar yang menekankan pada pengembangan afektif yakni pembelajaran yang diarahkan pada perkembangan keterampilan dan kepribadian (pendidikan karakter). Di sinilah perlunya pendayagunaan modal sosial dalam pendidikan karakter. Pembelajaran di sekolah (intrakurikuler \& ekstrakurikuler) memiliki peran strategis untuk mendayagunakan modal sosial baik dalam merencanakan, melaksanakan, maupun mengevaluasi pendidikan karakter. Jika modal sosial dikembangkan dengan baik dan benar, maka karakter menjadi kuat sehingga pendidikan karakter menjadi bagus. Hal ini akan mengakibatkan tercapainya kualitas karakter dan kualitas akademik peserta didik sesuai yang diharapkan. Pendayagunaan modal sosial yakni upaya mendatangkan hasil dan manfaat akan modal sosial merupakan langkah yang sangat strategis, mengingat kebersamaan, solidaritas, kesetiakawanan, gotong royong, kepercayaan (trust) menjadi syarat mutlak untuk mewujudkannya. Kebersamaan, solidaritas, toleransi, semangat bekerja sama, kemampuan berempati, merupakan modal sosial yang melekat dalam kehidupan bermasyarakat trmasuk di sekolah/satuan pendidikan, harus selalu dibangun.

Pendidikan adalah usaha kebudayaan yang bertujuan memberikan bimbingan dalam hidup tumbuhnya jiwa raga anak agar dalam kodrat pribadinya serta pengaruh lingkungannnya, mereka memperoleh kemajuan lahir batin menuju adab kemanusiaan yaitu kepribadian atau karakter tertinggi. (Suratman,1987, p. 12) Pendidikan sebagai tuntunan di dalam hidup tumbuhnya anak, menuntun segala kekuatan kodrat yang ada pada anak-anak agar mereka sebagai manusia dan anggota masyarakat dapat mencapai keselamatan dan kebahagiaan yang setinggi-tingginya (Samho, 2013,p. 75). Dalam konteks pendidikan karakter, pendidikan mengasah kecerdasan yang dapat membangun budi pekerti yang baik dan kokoh, hingga dapat mewujudkan kepribadian (persoonlijkhheid) dan karakter (Dewantara, 1977, p. 24). Dengan kata lain, pendidikan karakter merupakan usaha sadar untuk mempengaruhi perkembangan kualitas dan sifat yang diinginkan dari peserta didik yang memuat nilai etika dasar bersama yang luas yang harus ditanamkan sekolah secara eksplisit kepada peserta didik (Hoge, 2002, p. 104). Pendidikan karakter berhubungan dengan nilai-nilai, kebiasaan-kebiasaan yang baik, dan sikap yang positip guna mewujudkan individu yang dewasa dan bertanggung jawab, sebuah proses yang dilaksanakan secara terus-menerus dan memilliki makna lebih tinggi dari pendidikan moral (Zamroni, 2011, p. 173).

Bangsa Indonesia saat ini patut bangga dengan banyaknya prestasi yang diraih generasi muda, pelajar, mahasiswa dalam berbagai bidang di tingkat dunia, seperti olah raga, seni, sains dan teknologi. Namun di sisi lain muncul berbagai perilaku tak terpuji, menyimpang dan melanggar norma sosial yang melibatkan pelajar dan mahasiswa. Dunia pendidikan dinilai sebagai lembaga paling bertanggung jawab. Sistem pendidikan nasional dianggap telah "gagal" membangun karakter. Menurut Dewey "dimensi moral 
pendidikan akan gagal kecuali jika kita mempersiapkan siswa berpartisipasi dalam kehidupan sosial dan memajukan kesejahteraan masyarakat" (Dewey, 1964, p. 118) Kurikulum pendidikan nasional dianggap hanya menekankan pada aspek kognitif (penalaran) dibanding aspek afektif (sikap dan budi pekerti/karakter) dalam kegiatan proses pembelajaran. Dalam beberapa kasus pelanggaran di atas menunjukkan bahwa sistem pendidikan kita belum mampu membangun karakter bangsa (Surachmad, 2003, p. 114). Menurut (Megawangi, 2004, p. 1) peradaban sebuah lembaga maupun masyarakat akan terjadi penurunan ketika di dalam masyarakat tersebut terjadi demoralisasi.

Pendidikan bertanggung jawab dalam membangun karakter termasuk bekerja sama dengan orang lain (Fishman \& McCarthy, 1998 , p. 46). Oleh karena itu dibutuhkan landasan untuk pengembangan nilai-nilai positif dalam kehidupan sehari-hari. Landasan tersebut adalah nilai-nilai luhur yang bersumber dari modal sosial bangsa Indonesia yang terkandung dalam sila-sila Pancasila. Untuk itu menjadi kewajiban pemerintah untuk merumuskan kebijakan yang merancang, mengembangkan dan memfasilitasi pelaksanaan sistem pendidikan yang berkualitas dan berkarakter, yakni pendidikan yang mengantarkan peserta didik pada pembentukan karakter melalui pendayagunaan modal sosial. Sebagaimana pendapat (Fukuyama, 1995, p. 7) ...the area where governments probably have the greatest direct ability to generate sosial capital is education. Educational institutions do not simply transmit human capital; they also pass on sosial capital in the form of sosial rules and norms.

Pernyataan Fukuyama dipertegas Wang \& Morgan (2012, p. 5) bahwa pendidikan menjadi sumber pengembangan modal sosial yang mendorong dan menumbuhkan serta membangun keyakinan, kepercayaan dan partisipasi. Modal sosial merupakan kerja sama positif dari semua pihak baik sekolah, keluarga, maupun masyarakat, yang output nya melahirkan nilai-nilai saling hormatmenghormati, kebersamaan, toleransi, serta kejujuran. Menurut (Field, 2005, p. 19) modal sosial merupakan sumber daya yang dapat dimanfaatkan individu atau kelompok untuk menjalin hubungan kerja sama dengan individu atau kelompok lain, untuk mencapai tujuan sendiri atau bersama. Menurut Coleman dalam (Field, 2005, P. 24), modal sosial memberikan kontribusi positif bagi perkembangan modal manusia, sebagai sumber daya yang berguna bagi individu yang diperoleh melalui hubungan sosial. Modal sosial merupakan nilai-nilai kebaikan yang ada di dalam masyarakat. yang memberikan manfaat yang terlibat dan menjadi bagian dalam struktur masyarakat. Modal sosial juga dapat dikatakan sebagai sumber daya yang melibatkan harapan terhadap hubungan timbal balik, dan harapan terhadap individu agar terlibat dalam jaringan yang hubungannya diatur oleh tingkat kepercayaan dan nilai bersama yang tinggi (Liou \& Chan, 2088, p. 103). Modal merupakan asset hubungan sosial yang meliputi norma-norma dan nilai-nilai, kepercayaan, kejujuran, saling memahami, toleransi, bekerja sama, kolaborasi dan menjalin hubungan timbal balik yang memungkinkan seseorang bekerja dengan orang lain, memberikan kepercayaan dan dapat dipercaya dan menjalin hubungan secara aktif dengan yang lain di dalam masyarakat dalam rangka mencapai tujuan bersama (Putnam, 2000, p. 23).

Modal sosial memiliki hubungan erat dengan pendidikan karakter dalam proses pembelajaran dan keberhasilan pencapaian tujuan pendidikan. Hal ini diperkuat dengan tujuan pendidikan dasar, yaitu meletakkan dasar kecerdasan, kepribadian, akhlak mulia, dan keterampilan untuk hidup mandiri. Di samping itu juga sesuai dengan Undang Undang Sistem Pendidikan Nasional, No.20 tahun 2003, tentang tujuan pendidikan (Depdiknas, 2003, p. 5). Modal sosial memberikan dukungan bagi penguatan pendidikan karakter di sekolah. Sebagaimana pernyataan yang dikemukakan oleh Ronald Burn, Nan Lin dan Alejandro Portes, bahwa modal sosial merupakan sumber daya sosial yang dapat diperoleh individu melalui manfaat atau kebaikan hubungan dengan individu dan kelompok lain, yang pada dasarnya merupakan sifat individu (Grootaert, et,al, 2004, p.3). Krisis karakter secara nasional pada saat ini dapat memperburuk identitas sosial dan budaya. Salah satu faktornya adalah peran modal sosial yang lemah. Oleh karena itu, elemen-elemen modal sosial sangat dibutuhkan dalam mendukung pendidikan karakter. (Dwiningrum, 2013, p.1)

Dalam kaitannya pendayagunaan modal sosial dalam pendidikan karakter, SD 
Muhammadiyah Sapen Yogyakarta dan SD Budi Mulia Dua Yogyakarta memiliki ciri khusus. Keduanya juga mempunyai perbedaan dasar dalam visi dan misi, serta paradigma pengembangan sekolah. Namun, sejauh ini masih belum diketahui bagaimana bentuk pendayagunaan modal sosial dalam pendidikan karakter masing-masing sekolah. Oleh karena itu, penting dilakukan penelitian untuk menganalisis pendayagunaan modal sosial pada budaya sekolah dan proses pembelajaran dalam pendidikan karakter; menemukan perbedaan dan ciri khas pendayagunaan modal sosial pada budaya sekolah dan proses pembelajaran dalam pendidikan karakter di SD Sapen dan SD Budi Mulia Dua Yogyakarta.

Penelitian pendayagunaan modal sosial dalam pendidikan karakter di SD Sapen dan SD Budi Mulia Dua Yogyakarta ini mengeksplorasi ukuran modal sosial Grootaert, Narayan, Jones dan Woolcock, "SC-IQ's Six Dimension" dalam bukunya yang berjudul "Measuring Social Capital: An Integrated Social Capital". Keenam dimensi modal sosial tersebut adalah: kerja sama dan tindakan kolektif, kelompok dan jaringan, kepercayaan dan solidaritas, informasi dan komunikasi, kohesi dan inklusi sosial, serta pemberdayaan. Selain keenam dimensi modal sosial tersebut penelitian ini juga menggunakan dimensi modal sosial Coleman dan Putnam yang tidak termasuk dalam keenam dimensi aspek modal sosial, seperti aspek modal sosial hubungan kewenangan/authority relationship, norma efektif, bonding, bridging dan linking (aspek modal sosial yang dikembangkan Woolcock, 1999 \& World Bank, 2000).

\section{METODE PENELITIAN}

Penelitian ini adalah penelitian kualitatif, dengan paradigma naturalistik studi multi kasus. Penelitian naturalistik, menggunakan actual setting, bersifat deskriptif, mengutamakan proses dari pada hasil, menganalisis secara induktif, dan "makna" dalam penelitian kualitatif menjadi perhatian utama. (Bogdan, 1982, pp. 4-5), Penelitian ini mendasarkan data langsung, peneliti sebagai instrumen utama dalam memperoleh data. Penelitian ini menggunakan rancangan studi multi kasus. Seperti dikemukakan Bogdan et al. (1982, p. 62) "when researchers study one or more subject, setting or depositories of data they are usually doing what we call multi-case studies". Studi multi kasus mengkaji beberapa subjek tertentu dan memperbandingkannya dalam persamaan dan perbedaan. (Wahab, 1999, p. 92).

Berdasarkan kondisi dan lingkungan objek penelitian yang berbeda, peneliti menggali data melalui observasi, wawancara mendalam, dan dokumentasi. Penelitian di lapangan dilakukan pada bulan Juli 2012 sampai dengan bulan Desember 2012. Teknik pengumpulan data menggunakan pengamatan partisipan atau observasi, wawancara mendalam, dan dokumentasi. Observasi dilakukan secara sistematis terhadap kejadian-kejadian yang langsung ditangkap pada waktu peristiwa terjadi (Ahmadi, 2002, p. 70). Teknik observasi partisipasi dengan cara terlibat langsung secara aktif bersama objek yang diteliti. Wawancara terbuka dilaksanakan berdasarkan pedoman wawancara, sumber data penelitian juga dikumpulkan melalui pengkajian dokumen yang relevan.

Untuk menguji validitas data, data yang terkumpul diverifikasi terlebih dulu. Keabsahan data dilakukan melalui konfirmasi hasil observasi, wawancara dengan informan, dan konfirmasi dokumen dengan hasil wawancara. Uji kredibilitas data dilakukan dengan memperpanjang waktu pengamatan, meningkatkan ketekunan, triangulasi data, analisis kasus negatif, member check, dan menggunakan bahan referensi. Tahap analisis data menggunakan analisis data kualitatif model interaktif dari Miles \& Huberman (1992, pp. 16-17). Analisis data kualitatif model interaktif dilakukan secara berlanjut, berulang dan terus-menerus di dalam melaksanakan pengumpulan data/data collection, reduksi data/data reduction, penyajian data/data display, mengambil kesimpulan/conclusions drawing/verification.

\section{PEMBAHASAN}

\section{Pendayagunaan Modal Sosial dalam Pendidikan Karakter pada Budaya Sekolah}

Pendidikan karakter di SD Sapen dan SD Budi Mulia Dua pada dasarnya ditanamkan dan dilaksanakan melalui seluruh rangkaian aktivitas pembelajaran. Hal ini memperkuat pandangan Ryan dan Baohlin dalam 
tulisan Benninga dkk, yang berjudul "The Relationship of Character Education Implementation and Academic Achievement in Elementary Schools" bahwa pendidikan karakter sesuai dengan kurikulum, pendidikan karakter dapat ditanamkan di manapun dalam penyampaian kurikulum. Mengajar dan belajar adalah tindakan yang memiliki muatan nilai moral/karakter (Zamroni 2010, p. 71).

Aplikasi pendidikan karakter dalam budaya sekolah di SD Sapen mencakup pembiasaan budaya sekolah seperti: budaya disiplin, budaya yang menanamkan nilai karakter bagaimana arti penting dan manfaat dari kepatuhan terhadap norma; budaya kerja keras, membangun karakter yang tidak mudah menyerah; budaya persaingan, menanamkan semangat bersaing dalam hal-hal yang positif, untuk meraih yang terbaik dalam kehidupan; budaya kepemimpinan, membentuk pribadi yang memeliki karakter unggul dan dapat menjadi teladan bagi yang lain. Selain itu terdapat program monitoring activity yang dilakukan pada waktu kedatangan sampai kepulangan, seperti: datang tepat waktu, latihan pagi, tadarus Al-Qur'an, hafalan surat pendek, sholat Dhuha, sholat wajib; dan sejumlah program pengembangan diri seperti program afektif, berpakaian rapi, makan dan minum sambil duduk; kegiatan pembiasaan 5S, yakni senyum, salam, sapa, sopan, santun, kegiatan keteladanan, kegiatan pratiotisme, pengembangan bakat dan kreativitas serta program unggulan, seperti: kelas alternatif, pemutaran film edukasi (movie box), pustakawan kecil, story reading, library goes to class dan library in the car. Pembinaan Siswa Berprestasi: Pembinaan Olimpiade Matematika, Agama, Bahadsa dan Olahraga. Outdoor Learning \& Trainning: Kebersihan dan Kesehatan Lingkungan: Semultis, Semulrib, Anak K-Link, One Child One Tree, Triwisada, Bergada Hijau, Hubungan Sekolah dengan Orangtua dan Masyarakat Masing-masing program ini menanamkan nilai karakter berdasarkan tujuan target program.

Pendidikan karakter di SD Budi Mulia Dua dikenal dengan Character Building, pendidikan karakter yang diimplementasikan dalam rangkaian aktivitas proses pembelajaran peserta didik. Pendidikan karakter dengan melalui pendayagunaan modal sosial juga diterapkan dalam budaya sekolah yang dimulai sejak datang ke sekolah sampai waktu pulang diantaranya adalah: waktu kedatangan, kegiatan opening, etiket tata cara saat belajar, waktu Istirahat/snack time waktu ishoma/ istirahat, sholat, makan dan waktu kepulangan. Selain itu juga terdapat program karakter yang meliputi: Kebersihan dan kepedulian terhadap lingkungan yang dikenal dengan GretPapat LungoIjo, Area sekolah area yang bersih, indah, dan nyaman, Program piket, Jam makan, Sholat, Kamar mandi, Sampah, Kertas bekas, Sandal, Jam iqra; Sekolah Damai: Anti Bulying dan Vandalisme, Religius Activities, Nasionalisme dan Patriotisme, Pengembangan Bakat dan Kreativitas, Home stay, Hubunga Sekolah dengan Orangtua dan Masyarakat. Penjelasan pendayagunaan modal sosial dalam pendidikan karakter pada budaya dan program sekolah di SD Sapen dan SD Budi Mulia Dua dapat diperinci sebagai berikut.

\section{Pendayagunaan Modal Sosial Kerja Sama dan Tindakan Kolektif dalam Pendidikan Karakter}

Pendayagunaan modal sosial kerja sama dan tindakan kolektif dalam pendidikan karakter di SD Sapen dapat dilihat mulai dari saat kedatangan sampai kepulangan. Guru bekerja sama dengan karyawan, petugas keamanan, dan peserta didik yang bertugas, menyambut kedatangan peserta didik dengan berjabat tangan sebelum menuju kelas masing-masing. Selama proses pembelajaran guru bekerja sama dengan peserta didik dalam penyampaian mata pelajaran, dan pemecahan masalah pembelajaran Kerja sama juga terlihat dalam tugas kebersihan kelas, dan pelaksanaan shalat berjamaah. Pada acara peringatan hari-hari besar Islam atau event-event nasional, peserta didik bekerja sama mensukseskan acara yang dilaksanakan. Kerja sama dan tindakan kolektif juga dibangun dalam program lain seperti: monitoring activity, program pengembangan diri, kegiatan pembiasaan sikap 5S, kegiatan keteladanan, kegiatan patriotisme dan program unggulan. Kerja sama dan tindakan kolektif di SD Budi Mulia Dua, dalam implementasi pendidikan karakter juga diterapkan pada setiap pembelajaran peserta didik yang dimulai sejak kedatangan atau lebih dikenal dengan kegiatan opening yang meliputi pembiasaan $3 \mathrm{~S}$, senyum, sapa dan salam antara guru dan peserta didik, religious activities, kebersihan kelas dan lingkungan sekolah, etika makan, hari bersih dan program 
lain seperti program living value, greetPapat Lungoljo, dan sekolah damai.

\section{Pendayagunaan Modal Sosial Kelompok dan Jaringan Dalam Pendidikan Karakter}

Pendayagunaan modal sosial kelompok dan jaringan dalam pendidikan karakter SD Sapen dan SD Budi Mulia Dua, jika dilihat dari pelaksanaannya berhubungan dengan kegiatan intrakurikuler dan ekstrakurikuler. Dalam kegiatan intrakurikuler lebih berhubungan dengan kegiatan pembelajaran yang menuntut sekolah menjalin hubungan dengan lembaga lain guna memberikan pengetahuan, pemahaman dan pengertian kepada peserta didik berkaitan dengan mata pelajaran yang sedang dipelajari. Hal ini mengajarkan kepada peserta didik sikap penghargaan dan penghormatan kepada orang lain, menanamkan arti penting bekerja sama dan berhubungan dengan kelompok lain.

Pendayagunaan modal sosial kelompok dan jaringan di SD Sapen dilaksanakan dengan menjalin hubungan dengan kelompok/institusi lain seperti kunjungan ke Laboratorium Fakultas Peternakan UGM untuk mendapatkan pemahaman bagaimana menggunakan peralatan laboratorium. SD Sapen juga menjalin hubungan dengan institusi kepolisian untuk mendapat penjelasan bagaimana tertib lalu lintas, bahaya merokok, narkoba, dll. Menjalin hubungan dengan penerbitan, Kedaulatan Rakyat, untuk mendapat pengetahuan tentang proses pencetakan dan penerbitan surat kabar; mendatangkan native language ketika belajar bahasa asing dan sebagainya. Kegiatan ini disebut fieldtrip/ outdoor learning. Pendayagunaan kelompok dan jaringan dalam pendidikan karakter di SD Sapen juga dilaksanakan pada kegiatan ekstrakurikuler seperti acara bakti sosial membantu korban bencana, perayaan hari-hari besar Islam dan perayaan nasional Melakukan pertemuan dengan warga masyarakat yang memberikan keteladanan kepada peserta didik pentingnya menjalin hubungan dengan kelompok (masyarakat) dan lain sebagainya.

SD Budi Mulia Dua dalam pendayagunaan kelompok dan jaringan dalam rangka menanamkan pendidikan karakter juga dilakukan melalui kegiatan intrakurikuler dan ekstrakurikuler. Pada kegiatan intrakurikuler pendayagunaan modal sosial kelompok dan jaringan ini tidak sama persis seperti yang dila- kukan di SD Sapen. Hal itu terkait dengan ragam program karakter yang dikembangkan. Ada kesamaan dalam pelaksanaan field trip. Sementara untuk kegiatan ekstrakurikuler pendayagunaan modal sosial kelompok dan jaringan dilakukan pada beberapa kegiatan yang sama seperti dilakukan oleh SD Sapen perbedaannya pada kegiatan home stay. Kegiatan ini dilaksanakan oleh peserta didik SD Budi Mulia Dua dengan menginap di rumah salah satu masyarakat di suatu desa atau di suatu tempat kerajinan atau home industri tertentu. Peserta didik diperkenalkan dengan kelompok masyarakat yang tujuannya adalah untuk memahami kehidupan masyarakat, belajar langsung bagaimana cara menjadi petani, peladang atau menjadi pengrajin.

\section{Pendayagunaan Modal Sosial Kepercayaan dan Solidaritas Sosial dalam Pendidikan Karakter}

Pemanfaaatan modal sosial kepercayaan dan solidaritas dalam pendidikan karakter SD Sapen dapat dilihat dari sikap memegang kepercayaan ketika peserta didik mendapatkan tugas harian, peserta didik berusaha sendiri menyelesaikan tugas tanpa meminta bantuan kepada teman yang lain, sehingg yang tampak adalah suasana kompetisi antar peserta didik. Hal ini berbeda dengan suasana penyelesaian tugas di SD Budi Mulia Dua, peserta didik yang telah selesai mengerjakan tugasnya akan membantu temannya yang merasa kesulitan dalam mengerjakan tugas dengan memberikan bimbingan. Pendidkan karakter yang ditanamkan dari dua suasana yang berbeda tersebut juga menghasilkan sikap karakter yang berbeda. Pada peserta didik di SD Sapen tumbuh sikap mandiri, kepercayaan diri yang tinggi, disiplin, kejujuran dan penghargaan terhadap prestasi. Sementara di SD Budi Mulia juga tumbuh sikap karakter percaya diri mampu memberikan bimbingan kepada temannya, ketulusan dan solidaritas yang tinggi.

Pendayagunaan modal sosial solidaritas dalam pendidikan karakter, baik di SD Sapen maupun di SD Budi Mulia Dua dapat dikatakan sama. Masing-masing memiliki program kunjungan wajib bagi anggota sivitas akademika (guru, peserta didik dan karyawan) untuk menjenguk apabila ada sivitas akademika/masyarakat di sekitar lingkungan sekolah yang terkena musibah seperti sakit, me- 
ninggal dunia. Juga memenuhi undangan hajatan atau undangan lain dari orang tua/masyarakat sekitar, serta bekerja sama membantu meringankan penderitaan korban bencana alam dan sebagainya.

\section{Pendayagunaan Modal Sosial Informasi dan Komunikasi dalam Pendidikan Karakter}

Pendayagunaan modal sosial informasi dan komunikasi dalam pendidikan karakter di SD Muhammadiyah Sapen dan SD Budi Mulia Dua hampir dapat dikatakan sama. Informasi tentang ilmu pengetahuan dan dunia pendidikan diberikan kepada peserta didik melalui buku-buku yang tersedia di perpustakaan, majalah sekolah yang diterbitkan, serta mading/majalah dinding yang ada di masing-masing kelas. Pendayagunaan informasi juga dikembangkan melalui media internet pada web sekolah masing-masing. Pendidikan karakter yang dibangun dan ditanamkan dengan memberdayakan modal sosial informasi adalah membentuk sikap kecintaan terhadap ilmu pengetahuan, disiplin, kemandirian, kepercayaan diri, penghargaan dan penghormatan, ketekunan, penguasaan ilmu pengetahuan dan orientasi prestasi. Pendayagunaan modal sosial informasi dalam implementasi pendidikan karakter berhubungan dengan komunikasi. Bentuk pendayagunaan komunikasi dalam pendidikan karakter di SD Sapen dan SD Budi Mulia Dua ditanamkan secara verbal dalam bentuk penyampaian pesan-pesan moral seperti pemberian nasehat tentang kebaikan dan keburukan kepada peserta didik. Komunikasi ini bisa berupa anjuran maupun teguran dari guru kepada peserta didik atau dari sesama peserta didik.

\section{Pendayagunaan Modal Sosial Kohesi dan Inklusi Sosial dalam Pendidikan Karakter}

Pendayagunaan modal sosial kohesi dan inklusi sosial dalam pendidikan karakter peserta didik adalah merupakan bentuk kebersamaan dan pelibatan peserta didik selama proses pembelajaran. Baik SD Sapen maupun SD Budi Mulia Dua memberdayakan modal sosial kohesi dan inklusi sosial dalam membangun kebersamaan antara guru, peserta didik dan sivitas akademika, keluarga dan masyarakat. Aspek kebersamaan lebih menonjol di SD Budi Mulia Dua dibanding SD Sapen. SD Budi Mulia Dua sejak waktu kedatangan hingga kepulangan guru berada satu ruangan kelas bersama peserta didik. Guru menyampaikan mata pelajaran, memberikan pendampingan, kegiatan tadarus alQur'an, shalat dhuha, shalat wajib dan istirahat makan semua dilakukan dalam ruangan kelas yang sama. Perbedaaan dengan SD Sapen pada tempat pelaksanaan momen kebersamaan yang tidak dilaksanakan di dalam ruangan kelas tetapi dalam ruangan yang semestinya digunakan.

Pelibatan peserta didik dalam proses pembelajaran di SD Budi Mulia Dua juga lebih menonjol di mana setiap peserta didik yang lebih pandai diajarkan untuk membantu peserta didik lain yang mengalami kesulitan dalam menerima materi pelajaran. Peserta didik dilatih mendampingi teman lain yang belum mampu memecahkan masalah pelajaran. Suasana ini berbeda di SD Sapen, meskipun peserta didik juga diajari memberikan pengertian mata pelajaran kepada temannya, namun masing-masing peserta didik juga dilatih berkompetisi dalam meraih prestasi terbaik.

\section{Pendayagunaan Modal Sosial Pemberdayaan dalam Pendidikan Karakter}

Pendayagunaan modal sosial pemberdayaan dalam pendidikan karakter di SD Sapen dan SD Budi Mulia Dua, lebih ditanamkan pada pengembangan kecerdasan, kemampuan dan bakat peserta didik selama proses pembelajaran. Peserta didik yang memiliki keunggulan dalam bidang Matematika, IPA, sain dan teknologi akan mendapatkan perhatian dan pelatihan khusus dari para guru pembimbing untuk kemudian dipersiapkan mengikuti lomba baik pada tingkat lokal, nasional maupun internasional. Sederet prestasi telah diraih oleh para peserta didik baik dari SD Sapen maupun SD Budi Mulia Dua (terlampir). Pemberdayaan tidak hanya didasarkan pada kemampuan dari peserta didik, tetapi juga digali dari berbagai program kurikuler yang dilaksanakan. Pemberdayaan akan ditindaklanjuti setelah dalam penggalian kemampuan selama proses pembelajaran program ekstrakurikuler ditemukan bakat peserta didik.

\section{Pendayagunaan Modal Sosial Norma dalam Pendidikan Karakter}

Pendayagunaan modal sosial norma dalam pendidikan karakter peserta didik di SD Sapen lebih banyak dan beragam dibanding 
SD Budi Mulia Dua. Namun demikian salah satu norma memiliki pengaruh kuat dibanding norma-norma yang lain adalah program afeksi. Program afeksi dengan pos afeksinya adalah bentuk pengawasan perilaku afektif peserta didik, meskipun berbentuk pembiasaan norma sederhana, namun pembiasaan norma ini sangat berpengaruh dalam menumbuhkan karakter kedisiplinan yang kuat. Menurut Mulyasa (2011, p. 166), pembiasaan adalah sesuatu perbuatan yang dilakukan berulang-ulang agar menjadi kebiasaan. Metode pembiasaan dalam psikologi pendidikan, disebut operant conditioning. Pembiasaan menimbulkan internalisasi nilai, penghayatan dan pendalaman nilai dengan cepat ke dalam diri pelaku. Proses pembiasaan disebut "conditioning". Proses ini akan menjelmakan kebiasaan (habit) dan kemampuan (ability), yang akhirnya akan menjadi sifat-sifat pribadi (personal habits) yang terperangai dalam perilaku sehari (Djumhana, 2001, p. 6). Hasil pembiasaan karakter disiplin, menumbuhkan kesadaran diri peserta didik dalam pelaksanaan norma yang diterapkan, sikap tanggung jawab serta kepedulian dalam menjalankan norma-norma lain yang dilaksanakan di sekolah. Hal tersebut berbeda dengan pendayagunaan modal sosial norma di SD Budi Mulia Dua. Pelaksanaan norma-norma yang ditetapkan tanpa diperkuat dengan pos afeksi seperti di SD Sapen memiliki konsekuensi tidak terlaksanannya norma-norma yang diagendakan Norma-norma yang diterapkan di SD Budi Mulia Dua lebih menekankan pada pemberian reward dan punishment, seperti dalam program khusus pembentukan karakter bullying dan vandalism dan program karakter lain seperti GretPapat LungoIjo.

Dalam pelaksanaan norma-norma tersebut SD Budi Mulia Dua memberikan reward, bagi peserta didik yang melaksanakan norma dengan baik. Selain reward juga terdapat punishment, bagi peserta didik yang tidak melaksanakan atau melanggar norma. Sesungguhnya banyak sisi kelemahan dari penggunaan metode reward dan punishmnent dalam pelaksanaan pendidikan. Penggunaan metode reward menurut Alfie Kohn seperti dikutip Utomo Dananjaya (2012:290) bahwa penggunaan reward dalam penerapan norma untuk jangka waktu lama bukan meningkatkan motivasi tetapi justru menurunkan motivasi peserta didik. Pemberian reward dalam belajar, dalam melaksanakan aturan atau norma yang telah ditetapkan seolah-olah mengindikasikan bahwa kegiatan belajar atau norma yang ditetapkan tidak menarik peserta didik, sehingga harus diiming-imingi imbalan atau hadiah. Demikian halnya dengan punishment pada dasarnya merupakan alat pendidikan yang tidak menyenangkan, bersifat negatif, meskipun bisa dijadikan cambuk atau motivasi belajar siswa meskipun dalam konotasi adanya tekanan atau motivasi lain di balik itu, yaitu menghindari hukuman. Peserta didik akan berusaha menghindari punishment dan berusaha keras untuk dapat memenuhi tugas belajar atau mentatati norma agar terhindar dari punishment (Indrakusuma, 1973, p.165). Hal ini mengindikasikan bahwa perbuatan menghindari hukuman bukan karena kesadaran yang tumbuh dari dalam diri peserta didik sendiri, tetapi karena adanya tekanan untuk mematuhi norma tersebut.

\section{Pendayagunaan Modal Sosial \\ Pendelegasian Wewenang dalam Pendidikan Karakter}

Pendayagunaan modal sosial pendelegasian wewenang dalam pendidikan karakter di SD Sapen dan SD Budi Mulia Dua Yogyakarta adalah bentuk pembelajaran praktik peserta didik atas ilmu yang telah didapatkan. Tujuannya karakter yang diharapkan dari pendelegasian wewenang kepada peserta didik adalah agar dalam kepribadian peserta didik tumbuh kemandirian, kepercayaan diri, penghargaan terhadap prestasi, menghormati orang lain dan memiliki sifat tolong menolong kepada sesama.

Program pendelegasian wewenang SD Muhammadiyah Sapen memanfaatkan program Triwisada (dokter kecil) bekerja sama dengan UKS. Program memotivasi peserta didik yang terlibat mendapatkan pengetahuan tentang kebersihan dan kesehatan. Ilmu yang diperolehnya ini kemudian disampaikan kepada yang lain dalam kapasitas dan tugasnya sebagai dokter kecil, membantu memberikan penjelasan atau penerangan kepada yang sakit dan dalam berbagai hal berhubungan dengan kebersihan dan kesehatan. Program pendelegasian wewenang yang lain seperti pustakawan kecil, program Bergada Hijau di mana peserta didik secara bergiliran ditunjuk menjadi petugas pengawas kebersihan lingkungan serta program polisi kecil yang ber- 
tugas mengatur lalu lintas kedatangan dan kepulangan peserta didik di SD Sapen Yogyakarta.

Di SD Budi Mulia Dua, pendayagunaan modal sosial pendelegasian wewenang kepada peserta didik dalam pendidikan karakter dilakukan dalam beberapa program seperti mentoring yang dilakukan peserta didik kelas tinggi kepada kelas rendah. Pendidikan karakter yang ditanamkan melalui pendelegasian wewenang ini adalah melatih jiwa kepemimpinan peserta didik, menumbuhkan kepercayaan diri dan kemandirian pada peserta didik. Selain program mentoring terdapat program volunteer atau program magang yang dilaksanakan dalam rangka melatih peserta didik untuk mempraktikkan ilmu yang telah diperoleh.

\section{Pendayagunaan Modal Sosial Bonding dalam Pendidikan Karakter}

Menurut Putnam bonding adalah modal sosial yang memperkuat hubungan internal di antara orang-orang yang berada dalam lingkungan yang sama (warga sekolah: guru, peserta didik, orang tua dan masyarakat di lingkungan sekitar sekolah). Bonding membantu mendorong hubungan timbal balik dan solidaritas, memperkuat ikatan ke dalam dan membangun loyalitas yang kuat dalam kelompok (Hauberer, 2011, pp.57-58).

Pendayagunaan modal sosial bonding dalam pendidikan karakter adalah menanamkan arti penting dari nilai hubungan internal yang saling menguatkan dalam rangka mencapai tujuan. Bonding lebih berorientasi pada upaya mempererat hubungan internal seluruh sivitas akademika. Hubungan timbal balik antara kepala sekolah dan guru, guru dan guru, guru dan karyawan, guru dan peserta didik yang disandarkan pada tujuan untuk memperkuat identitas almamater SD Sapen. Pendayagunaan modal sosial bonding dalam pendidikan karakter di SD Sapen dilakukan tidak hanya antara sivitas akademika dengan peserta didik, tetapi juga dengan wali murid dan juga masyarakat di lingkungan sekitar SD Sapen, seperti dalam pertemuan komite sekolah, pertemuan pengajian wali murid atau pertemuan dengan masyarakat di sekitar SD Muhammadiyah Sapen.

Tidak berbeda dengan pendayagunaan modal sosial bonding dalam pendidikan karakter peserta didik di SD Sapen, pendi- dikan karakter peserta didik melalui pendayagunaan modal sosial bonding di SD Budi Mulia Dua juga memberikan keteladanan penguatan hubungan internal antara sekolah, guru dan wali murid dalam wadah komite sekolah. Dalam kondisi tertentu sekolah juga melibatkan atau mengundang wakil masyarakat di sekitar lingkungan SD Budi Mulia Dua, ketika membicarakan kepentingan dari kedua belah pihak. Peserta didik SD Budi Mulia Dua sebagai obyek pendidikan karakter melalui pendayagunaan modal sosial bonding juga dilatih memperkuat hubungan internal sesama peserta didik dan sivitas akademika dalam berbagai aksi sosial, seperti menyelenggarakan flea market (pasar murah) yang bertujuan membantu orang miskin mendapatkan barang yang diinginkan dengan harga yang sangat murah. Selain flea market peserta didik juga ditumbuhkan semangat kebersamaan dan kepeduliannya mengadakan kegiatan penggalangan dana dan pengumpulan barang untuk membantu para korban bencana alam.

\section{Pendayagunaan Modal Sosial Bridging dalam Pendidikan Karakter}

Modal sosial bridging, dalam pandangan Putnam, adalah bentuk penguatan hubungan kerja sama eksternal yang dilakukan satu kelompok/lembaga dengan kelompok atau lembaga lain. Bridging digunakan untuk mendapatkan keuntungan atau manfaat eksternal dan menjamin pendistribusian informasi, serta melahirkan berbagai identitas dan hubungan timbal balik dari berbagai sisi (Hauberer, 2011, pp.57-58).

Intensitas pendayagunaan modal sosial bridging dalam pendidikan karakter di SD Muhammadiyah Sapen ditemukan lebih sering dan lebih kuat dibandingkan dengan yang terjadi di SD Budi Mulia Dua. Frekuensi kunjungan studi banding atau magang, baik dari lembaga pendidikan maupun lembaga pemerintahan dari luar negeri dan dari seluruh pelosok daerah di Indonesia ke SD Muhammadiyah Sapen sangat tinggi. Tidak heran jika SD Muhammadiyah Sapen meraih penghargaan Juara I Lomba Best Practice Pendidikan Karakter Tingkat Sekolah Dasar yang diselenggarakan Kementerian Pendidikan Nasional Direktorat Jenderal Pendidikan Dasar Direktorat Pembinaan Sekolah Dasar bertempat di Hotel Harris Bandung, 20-23 Nopember 2013. Dengan demikian, SD Muhammadiyah 
Sapen memperoleh penghargaan sebagai Juara I Nasional di Bidang Pendidikan Karakter. Prestasi yang dicapai peserta didik SD Sapen di tingkat nasional dan internasional, baik di bidang sain dan teknologi juga tergolong tinggi dibanding prestasi yang diraih SD Budi Mulia Dua. Bahkan di awal tahun 2015, SD Sapen Yogyakarta meraih Anugerah Citra Indonesia 2015 kategori The Best Performance Elementary School of The Year dari sebuah lembaga independen di Jakarta.

\section{Pendayagunaan Modal Sosial Linking dalam Pendidikan Karakter}

Menurut Woolcock (1999), linking adalah hubungan represetasi kewenangan secara vertikal antara seseorang dalam suatu kelompok atau lembaga dengan kelompok atau lembaga lain yang lebih tinggi. Hubungan ini lebih didasari pada kepentingan untuk mencapai tujuan yang diinginkan melalui perwakilan yang ditunjuk yang pada akhirnya memberikan kesejahteraan atau penguatan identitas kelompok yang diwakili. Dalam berbagai even lomba atau kejuaraan dalam bidang sain, olahraga dan seni, pada tingkat daerah, kota, provinsi, nasional dan internasional, baik SD Muhammadiyah Sapen maupun SD Budi Mulia Dua mengutus perwakilan dari peserta didik masing-masing yang telah mendapatkan pembinaan untuk mewakili sekolah masing-m,asing dalam berbagai even kejuaraan yang dilombakan. Penunjukan peserta didik sebagai perwakilan sekolah masing-masing dapat membentuk kepribadian peserta didik yang memiliki karakter, tanggung jawab, ketekunan, kegigihan, semangant bersaing, sportif, kebanggaan dan kepercayaan diri yang tinggi untuk dapat meraih kemenangan yang diharapkan. baik SD Muhammadiyah Sapen ataupun SD Budi Mulia Dua masing-masing telah memperlihatkan kemampuan masing-masing seperti prestasi yang telah diraih selama ini (lihat lampiran prestasi SD Muhammadiyah Sapen ataupun SD Budi Mulia Dua).

\section{SIMPULAN DAN SARAN}

\section{Simpulan}

Berdasarkan hasil dan pembahasan penelitian, pendayagunaan modal sosial dalam pendidikan karakter di SD Muhammadiyah
Sapen dan SD Budi Mulia Dua Yogyakarta dapat disimpukan bahwa:

Pendayagunaan modal sosial dalam pendidikan karakter di SD Sapen dan SD Budi Mulia Dua diaplikasikan dalam semua kegiatan pembelajaran baik intrakurikuler maupun ekstrakurikuler termasuk dalam budaya sekolah. Pendayagunaan modal sosial terbukti sangat mendukung dan memperkuat pendidikan karakter melalui penanaman (inkulkasi) nilai-nilai karakter dan keteladanan (model) yang dilakukan secara integral dan timbal balik oleh seluruh sivitas akademika, orang tua dan masyarakat. Aspek-aspek modal sosial yang didayagunakan dalam pendidikan karakter di SD Sapen dan SD Budi Mulia Dua antara lain: kerja sama dan tindakan kolektif, informasi dan komunikasi, kelompok dan jaringan, kepercayaan dan solidaritas, kohesi dan inklusi sosial, pemberdayaan, norma, pendelegasian wewenang, bonding, bridging dan linking

Outcome pendayagunaan modal sosial dalam pendidikan karakter tidak hanya memperkuat 18 pilar karakter dasar (Kemendiknas) seperti; religius, jujur, toleransi, disiplin, kerja keras, kreatif, mandiri, demokratis, rasa ingin tahu, semangat kebangsaan, cinta tanah air, menghargai prestasi, bersahabat, komunikatif, cinta damai, gemar membaca, peduli lingkungan, peduli sosial, dan tanggung jawab, tetapi juga memperkuat karakter lain, seperti: kebersamaan, kerja sama, kerja keras, solidaritas, keadilan, ketulusan, ketekunan dan kegigihan, keberanian, penghargaan, cinta ilmu pengetahuan, rasa ingin tahu, kritis, percaya diri dan kemandirian.

Perbedaan pendayagunaan modal sosial dalam pendidikan karakter di SD Sapen dan SD Budi Mulia Dua tergantung pada budaya sekolah yang ditanamkan, materi pelajaran yang disampaikan, program atau kegiatan yang diselenggarakan serta kemampuan guru dalam memberikan model (keteladanan) serta penanaman (inkulkasi) nilai karakter pada program yang dilaksanakan. Perbedaan pendidikan karakter melalui pendayagunaan modal sosial di SD Muhammadiyah Sapen lebih eksplisit dan terstruktur dibandingkan dengan di SD Budi Mulia Dua.

Ciri khas pendidikan karakter melalui pendayagunaan modal sosial di SD Sapen dan SD Budi Mulia Dua dapat ditemukan dalam budaya sekolah dan metode pembelajaran 
yang diaplikasikan. Pertama, Ciri khas pendidikan karakter di SD Sapen lebih berorientasi pada budaya disiplin, program afeksi dan metode penugasan. Nilai kedisiplinan direalisasikan dan didukung program afeksi. Orientasi pendidikan karakter dengan metode penugasan, budaya disiplin, dan program afeksi melalui pendayagunaan modal sosial menghasilkan peserta didik yang religius, disiplin, kerja keras, tekun, gigih, percaya diri, kemampuan bersaing, kreatif dan kritis. Kedisiplin menumbuhkan sikap penghargaan terhadap norma, aturan dan tata tertib, hak orang lain, hak dan kewenangan guru, sikap tanggung jawab peserta didik terhadap perilakunya sendiri dan terhadap komunitas di dalam kelas maupun di luar kelas.

Kedua, Ciri khas pendidikan karakter melalui pendayagunaan modal sosial di SD Budi Mulia Dua lebih berorientasi pada metode happy learning pendampingan dan kreativitas. Metode ini mempengaruhi pembentukan karakter dan menghasilkan peserta didik yang menghasilkan karakter religius, kebersamaan, menghargai perbedaan, berani, kreatif dan dinamis. Karakter kemandirian, penghargaan kepada orang lain, kerja sama, kebersamaan dan solidaritas menjadi output penting dari metode pembelajaran happy learning dan metode pendampingan.

Pendidikan karakter SD Sapen yang lebih eksplisit dan terstruktur dengan program afeksi, budaya disiplin, metode penugasan dan berbagai program karakter mampu membentuk karakter peserta didik yang disiplin, tanggung jawab, patuh terhadap norma-norma agama, sekolah, masyarakat, menghargai orang lain dan membawa SD Sapen meraih Juara I The Best Practice Pendidikan Karakter Sekolah Dasar Tingkat Nasional Bidang Pendidikan Karakter dan Anugerah Citra Indonesia 2015 kategori The Best Performance Elementary School of The Year. Disamping itu, telah melahirkan peserta didik yang memiliki skill, kemampuan pikir, kecerdasan dan kreativitas, terbukti dengan banyaknya prestasi peserta didik SD Sapen di tingkat nasional maupun internasional.

Sementara metode happy learning, pendampingan guru, program living value dan program karakter lain di SD Budi Mulia melahirkan suasana belajar yang menyenangkan, suasana ini mendorong kretivitas peserta didik, membangun suasana kekeluargaan antara peserta didik dengan guru pendamping. membekali peserta didik dengan berbagai pengetahuan yang didapatkan di sekolah dan diaplikasikan langsung di masyarakat.

Kelemahan SD Sapen dalam proses pembelajaran dan pendidikan karakter adalah bahwa dengan intensitas kegiatan pembelajaran, budaya disipin dan program karakter yang tinggi membuat peserta didik secara psikologis merasa dalam tekanan. Sedangkan SD Budi Mulia Dua dengan metode happy learning yang tidak terkontrol menyebabkan peserta didik berperilaku sesuai keinginannya sehingga cenderung kurang disiplin, kurang focus dan kurang semangat bersaing. Selain itu peniadaan pelaksanaan upacara bendera, dapat menyebabkan terdegradasinya rasa nasionalisme peseta didik.

Modal sosial adalah nilai-nilai kebaikan dalam hubungan kerja sama timbal balik positif individu atau kelompok, yang membentuk kepribadian dan karakter masyarakat dalam mencapai kesejahteraan hidup. Modal sosial dalam pendidikan karakter adalah nilainilai kebaikan dalam hubungan kerja sama timbal balik positif antara peserta didik, guru, sivitas akademika, keluarga dan masyarakat yang membentuk kepribadian dan karakter peserta didik dalam mencapai tujuan pendidikan. Pendayagunaan modal sosial dalam pendidikan karakter pada kegiatan ekstrakurikuler memiliki pengaruh yang sangat kuat terhadap pembentukan karakter dibanding dalam kegiatan intrakurikuler. Pendayagunaan modal sosial dalam pendidikan karakter dengan memadukan model karakter melalui budaya disiplin, program afeksi dan metode penugasan dengan metode happy learning dan pendampingan akan memperkuat pembentukan kepribadian dan karakter peserta didik yang religius, terpuji, unggul dan berprestasi.

\section{Saran}

Dengan melihat sekolah sebagai miniatur kehidupan bermasyarakat serta menyadari urgensi pendayagunaan modal sosial, maka disarankan kepada kepala sekolah, guru, peserta didik, tenaga kependidikan, orang tua, dan masyarakat untuk melakukan hal-hal sebagai berikut:

Kepala sekolah dapat menyusun kebijakan dan ketentuan di bidang pendidikan yang memberi ruang bagi setiap komponen sekolah untuk mempertahankan dan mening- 
katkan implementasi pendidikan karakter dengan pendayagunaan modal sosial di lingkungan sekolah.

Sekolah dapat menyusun kurikulum yang memberi ruang gerak yang luas bagi upaya pendayagunaan modal sosial dalam implementasi pendidikan karakter bagi peserta didik dalam berlatih dan belajar mengembangkan minat, bakat, dan kemampuannya masing-masing.

Guru mempunyai peran strategis dalam upaya mengelola dan mengembangkan model pembelajaran. Guru hendaknya memberi ruang bagi peserta didik untuk melakukan hal-hal yang terkait dengan implementasi pendidikan karakter melalui pendayagunaan modal sosial di sekolah.

Tenaga kependidikan, orang tua (keluarga) dan masyarakat hendaknya terlibat bersama-sama dan bertanggung jawab dalam menciptakan iklim kondusif yang menunjang keberhasilan implementasi pendidikan karakter melalui pendayagunaan modal sosial di sekolah.

\section{DAFTAR PUSTAKA}

Bogdan, Robert, C., et.al. (1982). Qualitative Research for Education: an Introductioan to Theoryand Methods, London: Allyn and Bacon Inc.

Depdiknas. (2003). UU RI No. 20 tahun 2003 tentang Sistem pendidikan nasional.

Dewantara, K. H. (1977). Bagian I: Pendidikan.Yogya:Majelis Luhur Persatuan Tamansiswa.

Dewey, J. (1964). Experience and education. New York: Adivision of Macmillan Publishing Co., Inc.

Dwiningrum, S. I. A. (2013). Nation's Character Education Based on the Social Capital Theory. Asian Social Science. 9 (12), 114, 2013.

Field, J. (2005). Social capital and lifelong learning. Great Britain: Policy Press.

Fishman, S,M, \& McCarthy, L.P. 1998. John Dewey and The Challenge of Classroom Practice, New York: Teacher College Press.
Fukuyama, F. (1995). Trust: The social virtues and the creation of prosperity. New York. Free Press.

Grootaert, Christiaan. et al. (2004). Measuring social capital: An integrated questionnaire. USA: printed on recycled paper.

Hoge, JD. (2002) Character education, citizenship education, and the Social Studies. The Social Studies; May/Jun 2002; 93, 3; ProQuest: 103-108.

Liou, Tung-Yuang \& Chang , Nai-Ying. (2008) The Applications of Social Capital Theory in Education Siuping Journal of Humanities and Social Sciences. 11, pp. 99-122; September 2008.

Megawangi, R.(2004).Pendidikan karakter: Solusi yang tepat untuk membangun bangsa.Jakarta:BP Migas.

Miles, M. B., \& Hubermen, A. M. (1992). Analisis data kualitatif. (Terjemahan Tjetjep Rohindi Rohadi). Jakarta: Universitas Indonesia Press.

Mulyasa, E. (2011). Manajemen pendidikan karakter. Jakarta: Bumi Aksara

Putnam, R. D. (2000). The prosperous community: Social capital and public life.TAP 4 (13).

Samho, B. (2013). Visi pendidikan Ki Hadjar Dewantara: tantangan dan relevansi. Yogyakarta: kanisius.

Suyanto, \& Hisyam, D. (2000). Refleksi dan reformasi pendidikan di Indonesia memasuki Milenium III. Yogyakarta: Adi Cita Karya Nusa.

Suratman, K. (1987). Pokok-pokok ketamansiswaan. Yogyakarta: Majelis Luhur Persatuan Taman Siswa.

Wahab, A. (1999). Menulis Karya Ilmiah. Surabaya: Airlangga University Press.

Wang, N.\& Morgan, W. John (2012). The Harmonious Society, Social Capital and Lifelong Learning in China: Emerging Policies and Practice International Journal of Continuing Education and Lifelong Learning. 
Woolcock, Michel,(1999).Managing Risk, Shocks, Opportunity in Developing Economic:The Role of Social Capital,In Gustav Ranis,ed.Dimension of Development, New Haven, CT:Yale Center for International \&Area Studies, 197.

Zamroni. (2010). Capita selecta of character education: The role of school in the development of student character. A reader. Yogyakarta: Graduate Program the State University of Yogyakarta.

Zamroni. (2011). dalam Darmiyati (edt). Strategi dan model implementasi pendidikan karakter di sekolah. Yogyakarta: UNY Press. 